\title{
DIFFERENTIATE FACTORS OF PREGNANT WOMEN WITH CHRONIC ENERGY DEFICIENCY OCCURRENCE IN BAJULMATI VILLAGE, WONGSOREJO DISTRICT, BANYUWANGI REGENCY 2019
}

Bisyamsi Nawaijaya Moediarso ${ }^{1}$, Perthdyatama Syifaq Budiono ${ }^{1}$, Mohammad Fata Fatihuddin', Theophilus Tan Zhu En ${ }^{1}$, Berli Arfani Rantam ${ }^{1}$, Ayu Liana Gunawan ${ }^{1}$, Masyithoh Wahyu Diani ${ }^{1}$, Anjelina Kristina Mogi', Koyuki Atifa Rahmi ${ }^{1}$, Auliai Khoirunnisa $^{1}$, Birgitta Vania Rarasati ${ }^{1}$, Cincin Hari Purwati ${ }^{2}$, Linda Dewanti ${ }^{3}$, Djohar Nuswantoro $^{3}$

${ }^{1}$ Medical Students, Faculty of Medicine, Universitas Airlangga, Surabaya, Indonesia ${ }^{2}$ Head of Puskesmas Bajulmati, Banyuwangi Regency, Indonesia, ${ }^{3}$ Community Medicine Coordinating Bureau, Faculty of Medicine, Universitas Airlangga, Surabaya, Indonesia

\begin{abstract}
Riskesdas result in 2013 showed that the prevalence of WUS/eligible women population who were pregnant and at risk of CED was $24,2 \%$. CED in pregnant women can cause abortion and premature birth, low birth weight babies and infant disability, children become malnourished and brain development is hampered, and children are at risk of developing metabolic diseases. In Bajulmati Village there were 15 pregnant women. $40 \%$ of 15 pregnant women suffer from CED. The purpose of this study was to determine differences between groups based on maternal age, maternal occupation, family income, previous pregnancy history, history of chronic illness, and maternal knowledge about nutrition in the incidence of pregnant women with CED in Bajulmati Wongsorejo Banyuwangi and differences in knowledge levels and attitudes towards behavior about nutrition after an intervention. An observational analytic, crosssectional research design using questionnaires and observations. The sample selection technique uses a total sampling technique. There were significant differences between groups based on family income in the incidence of CED in pregnant women and previous pregnancy history in the incidence of CED in pregnant women. The level of knowledge gained after the intervention was in the form of counseling to Prevent CED significantly.
\end{abstract}

\section{ARTICLE HISTORY}

Received: February 7, 2020

Revised: May 25, 2020

Accepted: June 25, 2020

Published: June 30, 2020

(Online)

doi: 10.20473/jcmphr.v1i1.20297

\section{KEYWORDS}

Pregnant women, CED, balanced nutrition, level of knowledge

\section{CORRESPONDING AUTHOR}

Linda Dewanti

$\bowtie$ lindaperisdiono@yahoo.com Community Medicine Coordinating Bureau, Faculty of Medicine, Faculty of Medicine, Universitas Airlangga, Jl. Mayjen. Prof. Dr. Moestopo 47 Surabaya 60131 Indonesia

\section{INTRODUCTION}

Essential public health efforts include the promotion of health, environmental health, maternal and child health, family planning, nutrition services, and prevention and control of diseases, as well as treatment. Of the six essential public health efforts available, there are issues to be addressed, namely the prevention and control of disease. Chronic Energy Deficiency (CED) is a lack of energy intake that lasts longer. Anthroprometically, CED can be established if MUAC $<23,5 \mathrm{~cm}$ or BMI is less than $18.5 \mathrm{~kg} / \mathrm{m} 2$. Indonesia is a country rich in natural resources but there are many cases of chronic energy deficiency (CED). This is caused by an imbalance in nutrient intake so that it can 
lead to imperfect body growth both physically and mentally. ${ }^{1}$

According to the 2007 Riskesdas results, the province of East Java is one of 10 provinces in Indonesia with a CED prevalence of women of childbearing age above the national prevalence $(13,6 \%)$. While the results of Riskesdas in 2013 showed that the prevalence of female population of childbearing age (ages 1549 years) was pregnant and at risk of CED in East Java by $29,8 \%$, while at the national level the prevalence of WUS population who were pregnant and at risk of CED was $24,2 \%$. This shows that the population of pregnant women and CED in East Java is still higher than at the national level. $^{2}$

The prevalence of CED risk in pregnant women (15-49 years) is $24.2 \%$, especially the highest prevalence found in adolescents (15-19 years) by $38.5 \%$ compared to the older group (20-24 years) of $30,1 \%$. The proportion of pregnant women with an energy adequacy level of less than $70 \%$ of the energy adequacy rate is slightly higher in rural areas compared to urban areas, which is $52.9 \%$ compared to $51.5 \%$. While the proportion of pregnant women with a protein adequacy level of less than $80 \%$ the protein adequacy rate is also higher in rural areas compared to urban areas that is $55.7 \%$ compared to $49.6 \% .^{2}$

Chronic energy deficiency is one thing that causes a high risk in a pregnancy. During pregnancy, energy needs increase by requiring an additional about 80,000 calories for approximately 280 days. ${ }^{3}$ Poor dietary patterns and poor portions are a common cause of chronic energy deficiency sufferers. ${ }^{4}$ Chronic energy deficiency can cause problems for pregnant women and the fetus they contain. To identify pregnant women who are at risk of chronic energy deficiency (CED), measurement of upper arm circumference (MUAC) and body mass index (BMI) can be used. If a pregnant woman has a MUAC size of less than 23,5 $\mathrm{cm}$ and or a BMI of less than $18,5 \mathrm{~kg} / \mathrm{m} 2$ then the pregnant woman has reached the risk limit for CED. ${ }^{5}$

\section{MATERIALS AND METHODS}

This is an observational analytic study with cross sectional research design. This research will find out the factors that distinguish the incidence of CED in pregnant women in Bajulmati Village, Wongsorejo District, Banyuwangi Regency. Collection in this study is to use primary data, namely data taken directly by researchers with questionnaires, the questionnaire used is a questionnaire to know the factors which distinguishes the incidence of CED in pregnant women. Data processing is done through several stages, the first stage of editing is the activity to check the questionnaire sheet and observation for completeness of the data so that if there is a discrepancy can be completed immediately by the researcher. The second stage of coding is to give a certain code or number to the questionnaire to make it easier when conducting tabulation and analysis. The third stage is the entry of entering data from the questionnaire into SPSS software version 17.0. Data analysis to see the difference was done by chi-square test and fischer exact. 
The population is pregnant women in Bajulmati Village, Wongsorejo District, Banyuwangi Regency. The sample selection technique uses total sampling with 15 pregnant women. The target sample is pregnant women in Bajulmati Village. In the study sample, researchers included criteria for the samples taken. Samples taken are based on inclusion criteria, which are characteristics of samples that can be included or deserve to be studied. Inclusion criteria in this study are: Pregnant women, willing to be respondents, able to communicate actively. Exclusion criteria: cannot read, write, hear.

The instruments used in this study were structured questionnaires, gauges, body scales, and stationery. The questionnaire instrument to measure the nutritional status of pregnant women in this study is a meter to measure MUAC and maternal height and scales to measure maternal weight. The questionnaire instrument to determine the age of pregnant women in this study was measured by 1 question in the questionnaire. The questionnaire instrument to find out the work of mothers in this study was measured by 1 question in the questionnaire. The questionnaire instrument to determine family income in this study was measured by 1 question in the questionnaire. The questionnaire instrument to determine the history of previous maternal pregnancy in this study was measured by 2 questions in the questionnaire. The questionnaire instru-ment to determine the history of suffering from chronic illness in this study was measured by 1 question in the question-naire. The questionnaire instrument to determine the knowledge of pregnant women about nutrition in this study was measured by 12 questions in the questionnaire with an
Alpha Cronbanch questionnaire value of 0,621 .

Variable Factors Distinguishing CED Incidence in Pregnant Women in Bajulmati Village, Wongsorejo Subdis-trict, Banyuwangi Regency in 2019 Dependent Variables are CED in pregnant women and Independent Variables are the age of pregnant women, maternal occupa-tion, family income, previous pregnancy history, history of chronic illness and levels of chronic illness and levels knowledge about nutrition. Test Validity According to Notoatmodjo (2010), validity is an index that shows the measuring instrument actually measures what is measured. ${ }^{6}$ The instrument used in this study was a questionnaire. To get valid and reliable data, the questionnaire must be tested for validity and reliability. Before the questionnaire was used in the study, the questionnaire was tested for validity using the Pearson product moment correlation formula. If the value of $r$ count is greater than $r$ table means it is valid whereas if the value of $r$ count is smaller than $r$ table means it is invalid. Reliability is an index that shows the extent to which a measurement tool can be trusted or reliable. This means showing the extent to which the measurement results remain consistent when measuring twice or more of the same symptoms, using the same measuring instrument. Reliability measurement using the help of computer software with Cronbach Alpha formula. A variable is said to be reliable if it gives an Alpha Cronbanch value $>0,60$. Validity and Reliability Test Results The questionnaire used in this study had carried out a reliability test with the results of the Alpha Cronbanch 0,621 , so the questionnaire was declared valid. 


\section{RESULTS}

Table 1. The results of the study below show the factors that are thought to distinguish the incidence of CED in pregnant women in Bajulmati Village, Wongsorejo District, Banyuwangi Regency in 2019

\begin{tabular}{lcc}
\hline & Frequency & Percentage (\%) \\
\hline Nutritional Status of Pregnant Women & 9 & 60 \\
Normal & 6 & 40 \\
CED & 15 & 100 \\
Total & & \\
\hline Age when pregnant & 11 & 73.3 \\
21-35 years old & 4 & 26.7 \\
$<21$ > 35 years old & 15 & 100 \\
Total & & \\
\hline Profession & 3 & 20 \\
Work & 12 & 80 \\
Does not work & 15 & 100 \\
Total & & \\
\hline Income & 53 & 33.3 \\
Above Regional Minimum Wages & 10 & 66.7 \\
Under Regional Minimum Wages & 15 & 100 \\
Total & & \\
\hline Previous Pregnancy & 12 & 80 \\
Ever pregnant & 3 & 20 \\
Never pregnant & 15 & 100 \\
Total & & \\
\hline History of Chronic Disease & 2 & 13.3 \\
Yes & 13 & 86.7 \\
No & 15 & 100 \\
Total & 10 & 66.7 \\
\hline Knowledge level & 5 & 0 \\
High & 15 & 100 \\
Moderate & & \\
Low & 15 & \\
Total & & \\
\hline & & \\
\hline
\end{tabular}


Table 2. Factors Differentiating CED Maternal in the Wongsorejo District, Banyuwangi Regency in 2019

\begin{tabular}{|c|c|c|c|c|}
\hline & Normal & $\begin{array}{l}\text { Nutritional } \\
\text { status of } \\
\text { CED }\end{array}$ & Total & $\begin{array}{c}\text { Significance } \\
\text { Value }\end{array}$ \\
\hline \multicolumn{5}{|l|}{ Age when pregnant } \\
\hline $21-35$ years old & $8(\%)$ & $3(\%)$ & $11(100 \%)$ & 0.235 \\
\hline$<21 />35$ years old & $1(\%)$ & $3(\%)$ & $4(100 \%)$ & \\
\hline \multicolumn{5}{|l|}{ Profession } \\
\hline Work & $3(100 \%)$ & $0(0 \%)$ & $3(100 \%)$ & .229 \\
\hline Does not work & $6(50 \%)$ & $6(50 \%)$ & $12(100 \%)$ & \\
\hline \multicolumn{5}{|l|}{ Income } \\
\hline Above Regional Minimum Wages & $5(100 \%)$ & $0(0 \%)$ & $5(100 \%)$ & $0.044 *$ \\
\hline Under Regional Minimum Wages & $4(40 \%)$ & $6(60 \%)$ & $10(100 \%)$ & \\
\hline \multicolumn{5}{|l|}{ Previous Pregnancy } \\
\hline Ever pregnant & $9(\%)$ & $3(\%)$ & $12(100 \%)$ & $0.044 *$ \\
\hline Never pregnant & $0(\%)$ & $3(\%)$ & $3(100 \%)$ & \\
\hline \multicolumn{5}{|l|}{ History of Chronic Disease } \\
\hline Yes & $1(50 \%)$ & $1(50 \%)$ & $2(100 \%)$ & 1,000 \\
\hline No & $8(\%)$ & $5(\%)$ & $13(100 \%)$ & \\
\hline \multicolumn{5}{|l|}{ Knowledge level } \\
\hline High & $7(70 \%)$ & $3(30 \%)$ & $10(100 \%)$ & \multirow{3}{*}{0.329} \\
\hline Moderate & $2(40 \%)$ & $3(60 \%)$ & $5(100 \%)$ & \\
\hline Low & $0(0 \%)$ & $0(0 \%)$ & $0(100 \%)$ & \\
\hline
\end{tabular}

From the table above, it can be seen that there were no significant differences between groups based on age during pregnancy, occupation, history of chronic illness, and the level of maternal knowledge in the incidence of CED in pregnant women, indicated by a significance value $>0,05$. There were significant differences between groups based on family income and previous pregnancy history in the incidence of CED in pregnant women, indicated by a significance value $<0,05$.

\section{DISCUSSION}

Maternal age is one of the factors that influence the nutritional status of pregnant women. In this study, there were no significant differences between groups based on the age of pregnant women in the incidence of CED. This is in accordance with research conducted by Wijayanti (2016) which states that there is no significant corellation between age and the incidence of CED in pregnant women. This is consistent with the theory which states that the best age to get pregnant is more than 20 years and less than 35 years in the hope that the nutrition of pregnant women will be better. ${ }^{7}$

However, based on data from research conducted by Triatmaja (2017) and Mulyaningrum (2009), maternal age is related to the prevalence of CED in pregnant women. This is because pregnant women who are young, ie less than 20 
years, require far more nutrients for fetal growth and growth of the mother's own body than pregnant women who are of ideal age, thereby increasing the risk of CED. ${ }^{8-9}$

Work is also thought to affect the occurrence of CED in pregnant women. In this study, there were no significant differences between groups based on the workings of pregnant women in the incidence of CED. This is in accordance with research conducted by Indriani et al (2014) which found no significant corellation between maternal work with CED in pregnant women. This is because work does not directly affect the nutritional status of the mother. However, different results were shown by several other studies. According to Mahmudiono (2017), many working mothers experience CED incidents. This is because pregnant women who work have less time in preparing food that affects the amount of food consumed so that it affects the nutritional status of pregnant women. On the contrary, according to Surasih (2005), mothers who do not work are IRT (Housewives), in fact many experience CED incidents. This is due to mothers who do not work just do not have the time to meet the required energy and do not have access to much information because of the lack of time between homework. Mothers also need a high energy intake because the workload that is done everyday is very much to do homework such as taking care of the house, children, and husband. ${ }^{10-12}$

In this study, family income provides a significant difference in the incidence of CED in pregnant women. This is in accordance with research conducted by Mahirawati (2014), which revealed a significant corellation between monthly income and the incidence of CED in pregnant women. This situation concludes that the proportion of CED pregnant women is higher for mothers from families with income less than Rp.1,120,000 in a month. The higher the level of family income, the higher the purchasing power of the family to meet household needs so that the nutritional status of pregnant women tends to be better so that it is less likely to risk CED compared to pregnant women who come from low socioeconomic status.

This study found significant differences between groups based on previous pregnancy history in the incidence of CED in pregnant women. This is consistent with research conducted by Mahmudiono (2017) that first-time pregnant mothers and young people tend to be more at risk of CED because the mother's body is not ready to fulfill the energy for fetal growth. In addition, pregnancy that is too frequent (a distance of $<2$ years) can cause malnutrition because it can deplete the body's nutritional reserves and reproductive organs are not yet perfect as before pregnancy. Mothers are also still in the breastfeeding period and must meet their nutritional needs during breastfeeding, where when they are breastfeeding they need extra calories every day to meet their nutrition and milk production (Handayani and Budianingrum, 2011). This can also be caused by more and more pregnant women, so the mother will become less concerned about her pregnancy because it is considered normal and has already been experienced, so that mothers do not pay much attention to their health compared to early pregnancy (Mahmudiono, 2017). Different results 
were found in a study by Wijayanti (2016), namely there was no significant corellation between parity and CED in pregnant women. This result is supported by research by Syafuruddin et al (2018) who also did not find a significant corellation between the number of children with the incidence of CED. ${ }^{11,13,14,15}$

In this study, there were no significant differences between groups based on a history of chronic illness in the incidence of CED in pregnant women. This is in accordance with research conducted by Wijayanti, 2016 which states there is no corellation between the history of the disease with the incidence of CED in pregnant women. Research conducted by Hidayati (2011) also showed results that there was no corellation between tuberculosis and diarrheal disease and the risk of CED in pregnant women. ${ }^{16}$

Chronic diseases that have occurred for a long time cause the mother's body has adapted to the increased energy needs, so it does not affect the incidence of CED. Conversely, there are research results that show a corellation between infectious diseases with Chronic Energy Deficiency Events (CED), Infectious diseases can act as a starter for malnutrition as a result of decreased appetite, impaired absorption in the channel digestion or increased need for nutrients by disease. The association of infectious diseases with poor nutrition is a reciprocal corellation, that is a causal corellation. Infectious diseases can worsen nutritional conditions and poor nutritional conditions can facilitate infection. Diseases that are commonly associated with nutritional problems include diarrhea, tuberculosis, measles and whooping cough. ${ }^{17}$
Mother's knowledge about nutrition is thought to influence the mother's diet in fulfilling balanced nutrition. One way to increase one's knowledge is through education, where the higher a person's education the higher the knowledge that person has. Education will enlighten a person, especially in the knowledge of nutrition in pregnant women. But a person's education is not the only guarantee of one's knowledge, but the higher a person's education is, the easier they will receive information, and the more knowledge he has. Mothers with high levels of education have a high interest to find out early on the kinds of nutrients needed by mothers while pregnant and preparing for pregnancy. With good knowledge, an individual will try to apply that knowledge into his life practice, such as the fulfillment of balanced nutrition during pregnancy. ${ }^{6}$

Research conducted by Suryaningsih and Trisusila (2017) found a significant corellation between the level of knowledge of pregnant women with the incidence of CED. Good knowledge about a person's nutrition, making that person will increasingly take into account the amount and type of food they choose to consume. Those who have good knowledge tend to use more rationally and knowledge about the nutritional value of these foods. The knowledge possessed by a mother will influence the decision making and also influence the behavior. Mothers with good nutritional knowledge are likely to provide adequate nutrition for their babies. However, in this study there were no significant differences between groups based on mother's knowledge about nutrition in the CED incident. The same results were also obtained in another study, 
there was no corellation between maternal knowledge and the incidence of CED. This is because even though the mother's knowledge about nutrition is already good, her application in fulfilling nutritional needs is still not applied. ${ }^{17}$

The study in Bajulmati Village, obtained high rates of CED pregnant women in Bajulmati Village, Wongsorejo District, Banyuwangi Regency. The results of data analysis found that the factors that significantly differ in the incidence of CED were family income and previous pregnancy history. The diagnosis of the community that causes the problem is the lack of knowledge of mothers regarding balanced nutrition in preparation and during pregnancy, the lack of mother's knowledge about health conditions that must be prepared before pregnancy, and the lack of pregnant women nutrition.

Community therapy conducted in the village of Bajulmati is nutrition counseling for adolescent classes targeting junior and senior high schools, administration of folic acid and iron tablets for brides, and giving PMT counseling for brides candidates for CED.

\section{CONCLUSION}

There were no significant differences between groups based on age during pregnancy, occupation, history of chronic illness, and the level of maternal knowledge in the incidence of CED in pregnant women and there were significant differences between groups based on family income and previous pregnancy history in the incidence of CED in pregnant women.
An evaluation of community therapy activities has been carried out. Based on the indicators of success, the three programs carried out were fully realized or the success rate was $100 \%$.

\section{ACKNOWLEDGMENT}

\section{REFERENCES}

1. Legesse, M., Abebe, Z. and Woldie, H. 2019. Chronic energy deficiency and associated factors among older population in Ethiopia: A community based study. PLOS ONE, 14(4)

2. Kemenkes RI. 2015. Profil Kesehatan Indonesia tahun 2014. Jakarta: Departemen Kesehatan RI.

3. Sandjaja. 2009. Risiko Kurang Energi Kronis (KEK) Pada Ibu Hamil Di Indonesia. Jakarta: Depkes RI.

4. Azizah, Anisatun and Merryana Adriani. 2017. Tingkat Kecukupan Energi Protein pada Ibu Hamil Trimester Pertama dan Kejadian Kurang Energi Kronis. Media Gizi Indonesia, 12(1) : 21-26.

5. Departemen Kesehatan RI Ditjen Pembinaan Kesehatan Masyarakat. 1994. Pedoman penggunaan alat ukur lingkaran lengan atas (LILA) pada wanita usia subur. Jakarta: Departemen Kesehatan RI.

6. Notoatmodjo, Soekidjo. 2010. Metodologi Penelitian Kesehatan. Jakarta : Rineka Cipta.

7. Arisman. 2010. Gizi Dalam Daur Kehidupan : Buku Ajar Ilmu Gizi. Jakarta: EGC.

8. Triatmaja, N. T. 2017. Faktor-Faktor yang Berhubungan dengan Status Kurang Energi Kronis (CED) Ibu Hamil di Kabupaten Kediri. Jurnal Wiyata, 4(2) :137-142

9. Mulyaningrum. 2009. Hubungan Faktor Risiko Ibu Hamil dengan 
Kejadian Bayi Berat Lahir Rendah (BBLR) Di Rumah Sakit Umum Barru. Media Gizi Pangan, 7(1).

10. Indriany, Helmiyati S., dan Astria B. 2014. Tingkat Sosial Ekonomi Tidak Berhubungan dengan Kurang Energi Kronis (KEK) pada Ibu Hamil. Jurnal Gizi dan Dietetik Indonesia, 2(3) :116125

11. Mahmudiono, T. 2017. Relationship Between Age, Gravida, And Working Status Against Chronic Energy Deficiency And Anemia In Pregnant Women. Amerta Nutrition, 1(2) : 7279.

12. Surasih, H. 2005. Faktor-Faktor yang Berhubungan dengan Kejadian KEK pada Ibu Hamil di Kabupaten Banjarnegara. Sarjana. Semarang. Universitas Negeri Semarang.

13. Handayani, S. And Budianingrum, S. 2011. Analisis Faktor Yang Mempengaruhi Kekurangan Energi Kronis Pada Ibu Hamil Di Wilayah Puskesmas Wedi Klaten. Jurnal Involusi Kebidanan, 1(1) : 42- 60.

14. Wijayanti, H. 2016. Faktor-faktor yang berhubungan Kekurangan energi
Pregnant Women With Chronic Energy Deficiency

kronik (KEK) pada ibu hamil di Puskesmas Jetis II Bantul Yogyakarta. Yogyakarta. Universitas 'Aisyiyah Yogyakarta.

15. Nurdin, M.S., Hadju, Veni., Thahir, Andi Imam A., and Ansariadi Ansariad. 2018. Determinants of Chronic Energy Deficiency among pregnant women in Jeneponto regency. Social Determinants of Health, 4(1)

16. Hidayati F. 2011. Hubungan antara pola konsumsi, penyakit infeksi, dan pantang makanan terhadap risiko kurang energi kronis (KEK) pada ibu hamil di Puskesmas Ciputat Kota Tangerang Selatan Tahun 2011. Jakarta. Universitas Islam Negeri Syarif Hidayatullah.

17. Suryaningsih, E.and Trisusilani, A. 2017. Hubungan Tingkat Pengetahuan Ibu Hamil Tentang Kurang Energy Kronik (KEK) Dengan Ukuran Lingkar Lengan Atas (LILA) Di Puskesmas Depok III Sleman Tahun 2016. Yogyakarta: Jurnal Permata Indonesia 